\title{
Kualitas Virgin Coconut Oil (VCO) Sebagai Minyak Goreng yang Dibuat dengan Metode Pengadukan dengan Adanya Penambahan Kemangi (Ocimum sanctum L.)
}

\author{
Riliani P. Maradesaa*, Feti Fatimaha, Meiske S. Sangia \\ aJurusan Kimia, FMIPA, Unsrat, Manado
}

\begin{tabular}{l}
\hline K A T A K U N C I \\
\hline VCO \\
Kemangi \\
Minyak goreng \\
Kualitas
\end{tabular}

\begin{tabular}{l}
\hline K E Y W O R D S \\
\hline VCO \\
Basil \\
Cooking oil \\
Quality
\end{tabular}

AVAILABLE ONLINE

25 Februari 2014

\begin{abstract}
A B S TR A K
Telah dilakukan penelitian untuk mengetahui kualitas VCO sebagai minyak goreng yang dibuat dengan menggunakan metode pengadukan dengan adanya penambahan kemangi (Ocimum sanctum) serta perbandingannya dengan VCO tanpa penambahan kemangi. Parameter kualitas yang diuji yaitu bobot jenis, bilangan peroksida, dan asam lemak bebas (FFA). Hasil penelitian menunjukkan bahwa penambahan kemangi tidak memberikan pengaruh yang baik terhadap kualitas VCO karena kualitas VCO kontrol lebih baik dibandingkan VCO kemangi pada semua tahap penggorengan.
\end{abstract}

A B S T R A C T
A research had been conducted to determine the quality of VCO as
cooking oil, prepared by mixing method, which was added with basil
(Ocimum sanctum) and to compare it with VCO without basil. Parameters
tested were specific weight, peroxide number, and free fatty acid. The
results showed that the addition of basil did not give a good effect on the
VCO quality which was reflected in the lower quality of basil-added VCO
than that of VCO without basil at each frying stage.

\section{Pendahuluan}

Virgin Coconut Oil (VCO) merupakan minyak kelapa murni yang dihasilkan dari daging buah kelapa tua yang segar. Beberapa metode yang digunakan dalam pembuatan VCO adalah pemanasan $\left(<95^{\circ} \mathrm{C}\right)$, fermentasi dan pancingan. Selain metode tersebut ada juga metode pengadukan. Pada metode pengadukan, dengan adanya pengadukan terus-menerus, maka molekul protein yang berfungsi sebagai emulsifier dapat rusak sehingga minyak dapat terpisah. Keunggulan dari minyak ini adalah jernih, tidak berwarna dan tidak mudah tengik (Anwar, 2011).

Dari segi produksi maupun potensi pasar, VCO merupakan potensi unggulan yang perlu dikembangkan di Sulawesi Utara. Pada umumnya VCO hanya digunakan sebagai suplemen dan tidak digunakan sebagai minyak goreng. Minyak goreng yang umum digunakan adalah minyak kelapa sawit karena minyak kelapa sawit memiliki harga yang lebih ekonomis dibandingkan VCO. Salah satu alternatif dalam meningkatkan kualitas, aktivitas serta tingkat penerimaan konsumen terhadap VCO adalah dengan menambahkan bahan alam yang mengandung komponen fungsional. Salah satu bahan alam tersebut adalah rempah-rempah (Gugule dan Fatimah, 2010).

Beberapa peneliti telah melakukan penelitian mengenai uji aktifitas antioksidan alami dari berbagai jenis rempah-rempah khas Indonesia seperti kemangi (Ocimum sanctum L.). Hasil penelitian Sumardi (2006) menunjukan bahwa kemangi (Ocimum sanctum L.) merupakan sumber antioksidan alami yang cukup baik karena memiliki faktor protektif tertinggi keempat dari 23 jenis rempah-rempah yang diteliti. Lebih lanjut Ayu et al. (2006) melaporkan bahwa penambahan kemangi dapat mengurangi ketengikan minyak kelapa sawit. Hasil penelitian Anwar (2011) dan Musdalifah 
(2011) menyatakan bahwa VCO yang dibuat dengan metode pengadukan dan VCO yang dibuat dengan metode pemanasan bertahap mengandung komponen tak tersabunkan yaitu $\alpha$-tokoferol. Meskipun demikian, adanya $\alpha$-tokoferol tersebut tidak menjamin bahwa kualitas VCO sebagai minyak goreng lebih baik dibandingkan minyak kelapa sawit komersial dan minyak kelapa komersial.

Berdasarkan uraian di atas penulis memandang perlu dilakukan penelitian tentang kualitas VCO sebagai minyak goreng yang dibuat dengan menggunakan metode pengadukan dengan adanya penambahan kemangi.

\section{Metode}

\subsection{Tempat dan Waktu}

Penelitian ini dilaksanakan selama 3 bulan mulai Agustus-Oktober 2013 yang bertempat di Laboratorium Kimia Organik dan Laboratorium Advans FMIPA UNSRAT Manado, sedangkan untuk analisis bilangan peroksida dan asam lemak bebas dilakukan di Laboratorium Baristand, Manado.

\subsection{Bahan dan Alat}

Bahan-bahan yang digunakan dalam penelitian ini adalah daging buah kelapa (Cocos nucifera L.), air kelapa, kemangi, kentang komersial, minyak kelapa sawit komersial, minyak kelapa komersial, aquades, air suling, asam asetat glasial, kloroform, $\mathrm{KI}$ jenuh, $\mathrm{Na}_{2} \mathrm{~S}_{2} \mathrm{O}_{3}$, larutan pati, etanol, indikator phenolftalein, $\mathrm{KOH}$, aluminium foil dan kertas saring. Peralatan yang digunakan dalam penelitian ini adalah mixer, blender, wadah-wadah plastik, timbangan analitik, erlenmeyer $250 \mathrm{~mL}$, buret, statif, klem, pipet tetes, waterbath, dan piknometer.

\subsection{Prosedur Penelitian}

\subsubsection{Pembuatan VCO menggunakan metode pengadukan (Gugule dan Fatimah, 2010)}

Daging buah kelapa yang sudah diparut ditimbang sebanyak $5 \mathrm{Kg}$ kemudian dicampur dengan $10 \mathrm{~L}$ air kelapa, kelapa parut diremas-remas selama \pm 10 menit dan diperas. Hasil perasan berupa santan didiamkan selama 2 jam sampai terbentuk 2 lapisan yaitu krim dan skim. Setelah terbentuk 2 lapisan, diambil krimnya secara hatihati. Krim tersebut kemudian diaduk menggunakan mixer selama 1 jam. Setelah itu krim dimasukkan ke dalam suatu wadah untuk didiamkan selama 10 jam sampai terbentuk 3 lapisan antara lain minyak, blondo, dan air. Minyak dipisahkan dengan cara membuka kran pada wadah plastik. Minyak yang telah dipisahkan kemudian disaring dengan kertas saring.

\subsubsection{Pembuatan VCO dengan penambahan kemangi menggunakan metode pengadukan (Gugule dan Fatimah, 2010)}

Daging buah kelapa yang sudah diparut ditimbang sebanyak $5 \mathrm{Kg}$ kemudian dicampur dengan $10 \mathrm{~L}$ air kelapa dan $125 \mathrm{~g}$ kemangi yang sudah diblender. Kelapa parut diremas-remas selama \pm 10 menit dan diperas. Hasil perasan berupa santan didiamkan selama 2 jam sampai terbentuk 2 lapisan yaitu krim dan skim. Setelah terbentuk 2 lapisan, diambil krimnya secara hatihati. Krim tersebut kemudian diaduk menggunakan mixer selama 1 jam. Setelah itu krim dimasukkan ke dalam suatu wadah untuk didiamkan selama 10 jam sampai terbentuk 3 lapisan antara lain minyak, blondo, dan air. Minyak dipisahkan dengan cara membuka kran pada wadah plastik. Minyak yang telah dipisahkan kemudian disaring dengan kertas saring.

\subsubsection{Perhitungan rendemen hasil}

Rendemen VCO dihitung berdasarkan bobot VCO yang diperoleh (g) dibandingkan dengan bobot kelapa parut yang digunakan (g).

Rendemen hasil $(\%)=$

$$
\frac{\text { bobot VCO yang diperoleh }(\mathrm{g})}{\text { bobot kelapa parut }(\mathrm{g})} \times 100 \%
$$

\subsubsection{Perlakuan Virgin Coconut Oil (VCO) pada penggorengan kentang (Sartika, 2009)}

Proses Penggorengan Menggunakan Deep Frying. Dimulai dengan memasukkan minyak kelapa murni (VCO) ke dalam ketel penggorengan sebanyak \pm 3 liter, kemudian ketel dipanaskan hingga suhu mencapai $160^{\circ} \mathrm{C}$. Setelah itu, sebanyak 100 gram kentang siap saji komersial digoreng selama 10 menit dan diaduk sebanyak 5 kali. Proses penggorengan dilanjutkan sampai pada penggorengan tahap 3.

\subsubsection{Analisis kualitas Virgin Coconut Oil (VCO)}

\section{(1) Bobot Jenis (Ketaren, 1986)}

Piknometer dibersihkan dan dikeringkan, kemudian diisi dengan minyak sampai meluap dan tidak terbentuk gelembung udara. Piknometer ditutup, minyak yang meluap dan menempel di bagian luar piknometer dibersihkan. Kemudian piknometer direndam dalam waterbath pada suhu $30^{\circ} \mathrm{C}$ selama 30 menit. Dengan hati-hati piknometer diangkat dari waterbath, dibersihkan dan dikeringkan. Piknometer beserta isinya ditimbang. Bobot minyak adalah selisih berat piknometer beserta isinya dikurangi berat piknometer kosong.

$$
\begin{aligned}
& \text { Bobot jenis VCO }\left(30^{\circ} \mathrm{C}\right)=\frac{a-b}{c} \\
& \mathrm{a}=\text { berat piknometer+minyak }(\mathrm{g}) \\
& \mathrm{b}=\text { berat piknometer kosong }(\mathrm{g}) \\
& \mathrm{c}=\text { volume minyak pada suhu } 30^{\circ} \mathrm{C}(\mathrm{mL})
\end{aligned}
$$

\section{(2) Bilangan Peroksida (Ketaren, 1986)}

Sebanyak 5 gram sampel dimasukkan ke dalam erlenmeyer $250 \mathrm{~mL}$, kemudian ditambahkan $30 \mathrm{~mL}$ campuran pelarut yang terdiri dari $60 \%$ asam asetat glasial dan $40 \%$ kloroform. Setelah minyak larut, ditambahkan $1 \mathrm{~g} \mathrm{KI}$ sambil dikocok kemudian didiamkan selama 30 menit dalam tempat gelap. Setelah itu ditambahkan $30 \mathrm{~mL}$ aquades. Kelebihan iod dititrasi dengan larutan $0,1 \mathrm{~N} \mathrm{Na}_{2} \mathrm{~S}_{2} \mathrm{O}_{3}$ sampai 
warna kuning hampir hilang. Ditambahkan $0.5 \mathrm{~mL}$ larutan pati $1 \%$. Titrasi dilanjutkan sampai warna biru mulai hilang. Hasilnya dinyatakan dalam miliekuivalen per 1000 gram minyak.

$$
\begin{aligned}
& \text { Bilangan Peroksida }=\frac{A \times N \times 1000}{G} \\
& A=\text { jumlah ml larutan } \mathrm{Na}_{2} \mathrm{~S}_{2} \mathrm{O}_{3} \\
& \mathrm{~N}=\text { normalitas } \mathrm{Na}_{2} \mathrm{~S}_{2} \mathrm{O}_{3} \\
& \mathrm{G}=\text { berat sampel (gram) }
\end{aligned}
$$

\section{(3) Asam Lemak Bebas (Ketaren, 1986)}

Sampel sebanyak 10-20 g dimasukkan ke dalam erlenmeyer $250 \mathrm{~mL}$, kemudian ditambahkan $50 \mathrm{~mL}$ etanol 95\%. Ke dalam campuran ditambahkan 3-5 tetes indikator phenoftalein. Selanjutnya dititrasi dengan larutan standar $\mathrm{KOH}$ $0.1 \mathrm{~N}$ hingga berwarna merah muda. Setelah itu dihitung jumlah $\mathrm{KOH}$ yang digunakan untuk titrasi dicatat untuk menghitung kadar asam lemak bebas.

Kadar asam (acid number) $=\frac{\mathrm{M} \times \mathrm{A} \times \mathrm{N}}{10 \mathrm{G}} \%$

$$
\begin{aligned}
M= & \text { bobot molekul asam lemak (minyak } \\
& \text { kelapa }=205 ; \text { minyak kelapa sawit=263) } \\
\mathrm{A}= & \text { volume } \mathrm{KOH} \text { untuk titrasi }(\mathrm{mL}) \\
\mathrm{N}= & \text { Normalitas larutan } \mathrm{KOH} \\
\mathrm{G}= & \text { berat sampel (gram) }
\end{aligned}
$$

\section{Hasil dan Pembahasan}

\subsection{Rendemen Virgin Coconut Oil (VCO)}

Rendemen merupakan rasio antara berat minyak VCO yang dihasilkan dengan berat kelapa parut yang digunakan. Rendemen dihitung untuk mengetahui kadar VCO yang diperoleh dari banyaknya kelapa parut yang digunakan. Pada penelitian ini, pembuatan VCO dilakukan dengan metode pengadukan. Pada metode pengadukan, dengan adanya pengadukan terus menerus, maka molekul protein yang berfungsi sebagai emulsifier dapat rusak sehingga minyak dapat terpisah (Koapaha dalam Anwar, 2011). Rendemen VCO dari pengolahan daging buah kelapa dengan metode pengadukan disajikan pada Gambar 1.

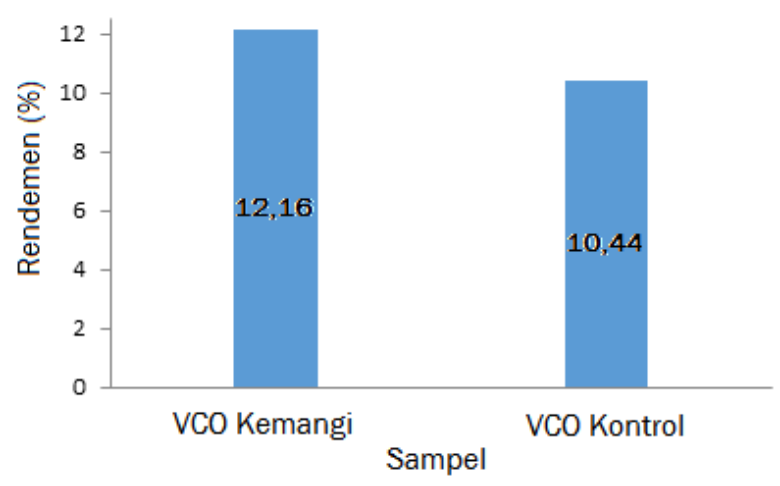

Gambar 1. Rendemen VCO dari pengolahan buah kelapa dengan metode pengadukan

Berdasarkan Gambar 1, diketahui bahwa VCO kontrol menghasilkan rendemen yang lebih banyak daripada VCO kemangi. Hal ini diduga disebabkan karena kemangi mengandung komponen-komponen yang dapat menghambat proses pemisahan minyak dengan air dalam emulsi santan (Gugule dan Fatimah, 2010).

\subsection{Bobot jenis}

Bobot jenis adalah perbandingan antara berat dari suatu sampel minyak dengan volume minyak pada suhu yang sama. Bobot jenis dari VCO dan VCO-kemangi yang dibuat dengan metode pengadukan disajikan pada Gambar 2.

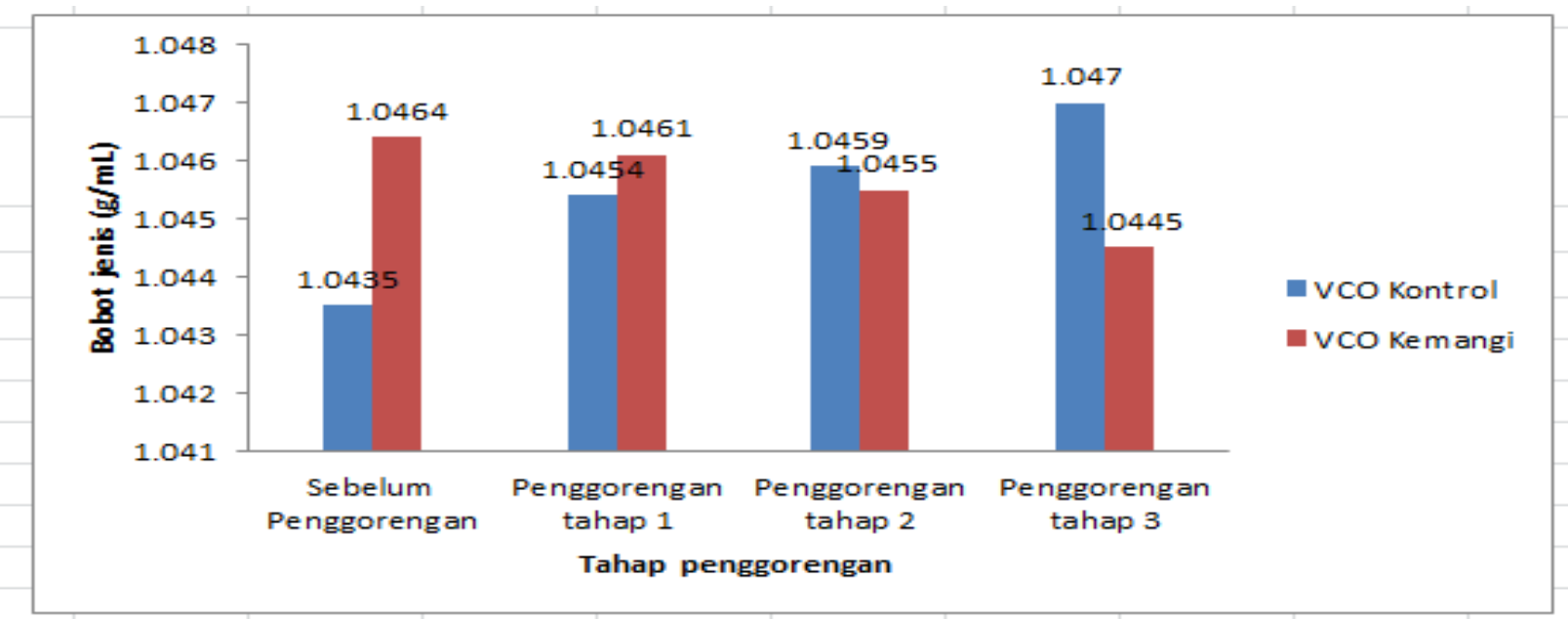

Gambar 2. Bobot jenis dari VCO dan VCO-kemangi yang dibuat dengan metode pengadukan, sebelum dan sesudah penggorengan

Dari Gambar 2 dapat dilihat bahwa bobot jenis dari VCO dan VCO-kemangi baik sebelum penggorengan sampai pada penggorengan tahap 3 tidak memenuhi standar APPC yaitu 0,915-0,920 $\mathrm{g} / \mathrm{mL}$. Bobot jenis minyak dipengaruhi oleh berat molekul dan komponen-komponen dalam minyak serta ketidakjenuhan komponen asam lemak minyak. Semakin banyak komponen dalam minyak, maka bobot jenisnya akan semakin tinggi (Anwar, 2011). Oleh karena itu, bobot jenis VCO kemangi 
cenderung lebih tinggi dibandingkan VCO kontrol dikarenakan adanya komponen dalam kemangi yang terlarut dalam minyak.

\subsection{Bilangan peroksida}

Bilangan peroksida adalah nilai terpenting untuk menentukan derajat kerusakan pada minyak atau lemak. Asam lemak tidak jenuh dapat mengikat oksigen pada ikatan rangkapnya sehingga membentuk peroksida. Hasil uji bilangan peroksida VCO dan VCO-kemangi disajikan pada Gambar 3.

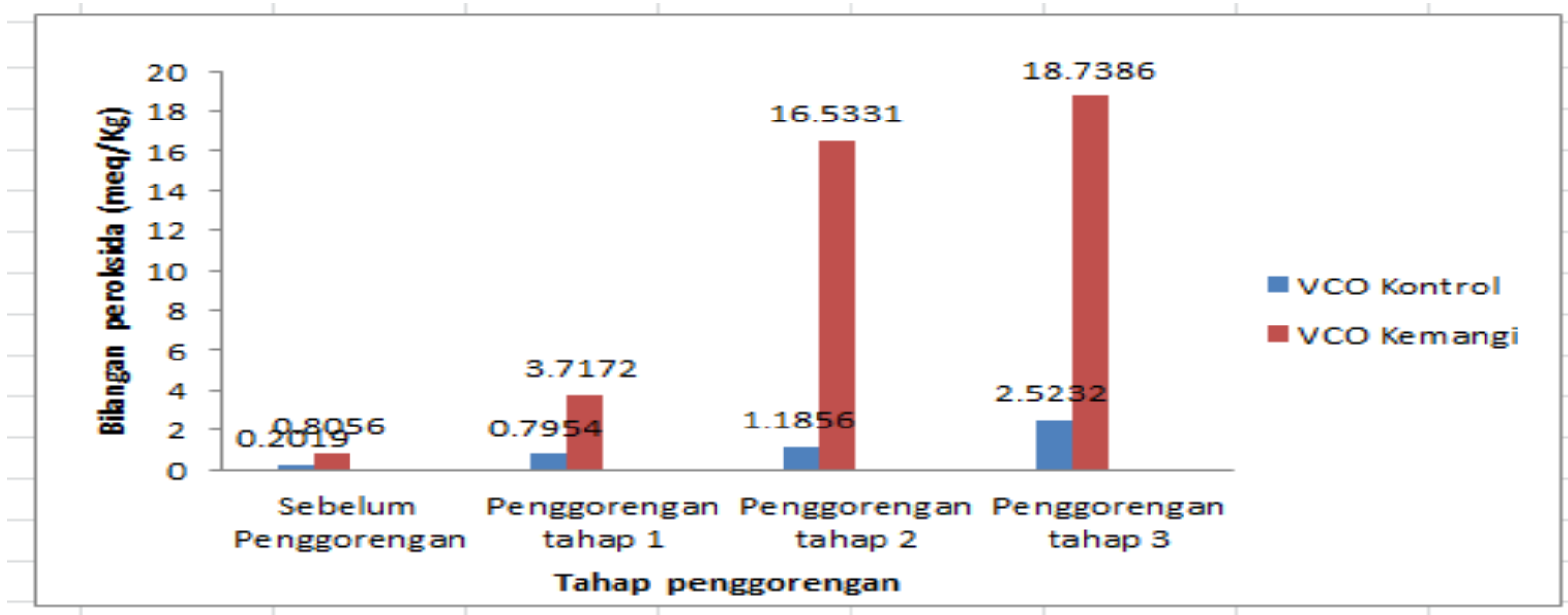

Gambar 3. Bilangan peroksida dari VCO dan VCO-kemangi yang dibuat dengan metode pengadukan sebelum dan sesudah penggorengan

Dari Gambar 3 dapat dilihat bahwa bilangan peroksida VCO pada semua tahap penggorengan masih memenuhi standar APPC yaitu $\leq 3 \mathrm{meq} / \mathrm{Kg}$. Setelah dilakukan proses penggorengan sampai pada tahap 3, bilangan peroksida semua sampel mengalami kenaikan. Hal ini disebabkan karena selama proses penggorengan, minyak dipanaskan secara terus menerus pada suhu tinggi dan mengalami kontak dengan oksigen dari udara luar yang memudahkan terjadinya reaksi oksidasi pada minyak. Terjadinya reaksi oksidasi dapat mengakibatkan bau tengik pada minyak yang berarti minyak akan rusak (Ketaren, 1986).

Semakin rendah bilangan peroksida maka kualitas minyak akan semakin baik (Ketaren, 1986). VCO kontrol pada semua perlakuan memiliki bilangan peroksida yang lebih rendah daripada VCO kemangi, sehingga dapat dikatakan bahwa penambahan kemangi pada pembuatan VCO tidak memberikan pengaruh yang baik dari segi bilangan peroksidanya. Adanya penambahan kemangi diduga menambah komponen antioksidan dalam VCO tetapi kombinasi antioksidan dari VCO tidak relevan sehingga perpaduan kedua antioksidan tersebut justru menaikkan bilangan peroksida.

\subsection{Asam lemak bebas}

Proses penting terbentuknya asam lemak bebas yaitu proses hidrolisis. Dengan adanya air, lemak dapat terhidrolisis membentuk gliserol dan asam lemak bebas. Asam lemak bebas dari VCO dan VCO-kemangi yang dibuat dengan metode pengadukan dapat dilihat pada Gambar 4.

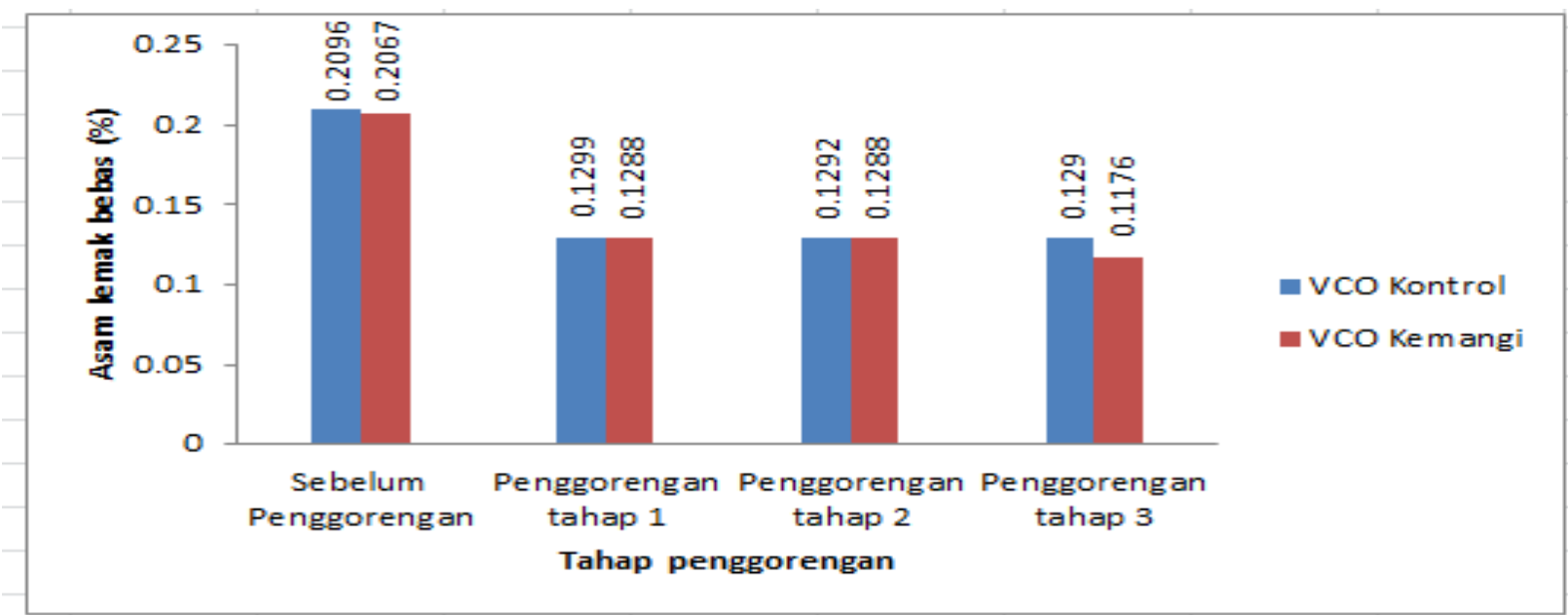

Gambar 4. Asam lemak bebas dari VCO dan VCO-kemangi yang dibuat dengan metode pengadukan sebelum dan sesudah penggorengan 
Dari Gambar 4 dapat dilihat bahwa asam lemak dari VCO dan VCO-kemangi baik sebelum penggorengan bahkan sampai pada penggorengan ketiga masih memenuhi standar APCC yaitu $<0.5 \%$. Setelah proses penggorengan, asam lemak bebas dari VCO dan VCO-kemangi mengalami penurunan. Penurunan kadar asam lemak bebas dari VCO dan vCo-kemangi yang diperoleh bertentangan dengan hasil kadar air yang semakin meningkat. Hal tersebut disebabkan karena dalam VCO terdapat air bebas sehingga tidak meningkatkan terjadinya reaksi hidrolisis. Adanya kandungan asam lemak bebas dalam VCO-kemangi yang lebih kecil dari VCO diduga disebabkan karena penambahan kemangi pada pembuatan VCO menyebabkan larutnya komponen-komponen non polar berupa minyak atsiri yang sudah terdistribusi di dalam minyak (Gugule dan Fatimah, 2010).

Dari hasil yang diperoleh, dapat dilihat bahwa vco kemangi pada semua perlakuan memiliki nilai asam lemak bebas yang lebih rendah dibandingkan VCO kontrol. Hal ini berarti penambahan kemangi memberikan pengaruh yang baik terhadap kualitas minyak.

\section{Kesimpulan}

Dari uji kualitas minyak yang telah dilakukan diperoleh bahwa berdasarkan uji bilangan peroksida, VCO memiliki kualitas yang lebih baik dibandingkan vCo-kemangi karena bilangan peroksidanya lebih rendah. Sedangkan berdasarkan uji asam lemak bebas, VCo-kemangi memiliki kualitas yang lebih baik karena asam lemak bebasnya cenderung lebih rendah dibandingkan asam lemak bebas VCO.

\section{Daftar Pustaka}

Ahmad, M. I., Lucia, C. M., Tineke, M. L., Jenny, E. A. K. 2013. Pengaruh Perbandingan Santan dan Air Terhadap Rendemen, Kadar Air dan Asam Lemak Bebas (FFA) Virgin Coconut Oil.

Anwar, F. 2011. Analisis Komponen Tidak Tersabunkan Dalam Virgin Coconut Oil (VCO) Yang Dibuat Dengan Metode Mixing [Skripsi]. FMIPA UNSRAT.

APCC. 2004. Asian and Pacific Coconut Community Standart For Virgin Coconut Oil. http://www. apccsec.org/document/VCNO.pdf [20 Agustus 2013]

Ayu, R., M. Manullang, dan M. Cornelia. 2006. Pengaruh Penambahan Ekstrak Daun Kemangi (Ocimum basilicum L.) Terhadap Ketengikan Minyak Kelapa Sawit. Jurnal IImu dan Teknologi Pangan. 2: 30
Gugule, S. dan F. Fatimah. 2010. Karakterisasi Virgin Coconut Oil (VCO) Rempah. Chem. Prog. 2: 104

Hendrawati, A. R. E. 2009. Uji Toksisitas Akut Ekstrak Etanol Daun Kemangi (Ocimum sanctum Linn.) Terhadap Larva Artemia salina Leach Dengan Metode Brine Shrimp Lethality Test [Laporan Penelitian]. Fakultas Kedokteran Universitas Diponegoro, Semarang.

Ketaren, S. 1986. Pengantar Teknologi Minyak Dan Lemak Pangan. UI Press, Jakarta.

Maryati, R. S. Fauzia. dan T. Rahayu. 2007. Uji Aktivitas Antibakteri Minyak Atsiri Daun Kemangi (Ocimum basilicum L.) Terhadap Staphylococcus aureus dan Escherichia coli. Jurnal Penelitian Sains \& Teknologi. 1: 30-33

Musdalifa. 2011. Analisis Komponen Tidak Tersabunkan Dari VCO Yang Dibuat Dengan Metode Pemanasan Bertahap. [Skripsi]. FMIPA UNSRAT.

Naibaho, O. H., P. V. Y. Yamlean dan W. Wiyono. Pengaruh Basis Salep Terhadap Formulasi Sediaan Salep Ekstrak Daun Kemangi (Ocimum sanctum L) Pada Kulit Punggung Kelincl Yang Dibuat Infeksi Staphylococcus aureus. Pharmacon. 2:27

Nevin, K. G. and T. Rajamohan. 2004. Beneficial effects of virgin coconut oil on lipid parameters and in vitro LDL oxidation. J. Biochem. 33:830835

Nevin, K. G. and T. Rajamohan. 2006. Virgin coconut oil supplemented diet increases the antioxidant status in rats. J. Food Chem. 99: 260-266

Sartika, R. A. D. 2009. Pengaruh Suhu Dan Lama Proses Menggoreng (Deep Frying) Terhadap Pembentukan Asam Lemak Trans. Makara, Sains. 13: 23-28

Sidik, S. L. 2013. Pengaruh Penambahan Emulsifier Dan Stabilizer Terhadap Kualitas Santan Kelapa [Skripsi]. FMIPA UNSRAT, Manado.

Sumardi, M. 1992. Aktifitas Antioksidan Alami Dari Berbagai Jenis Rempah-Rempah Khas Indonesia [Skripsi]. Fakultas Teknologi Pertanian IPB, Bogor.

Surbakti, M., Br. 2010. Karakterisasi Virgin Coconut Oil (VCO) Dari Tiga Daerah Sumber Kelapa Dengan Variasi Waktu. J. Kimia Mulawarman. 7: 78-81

Sutarmi dan H. Rosaline. 2006. Taklukkan Penyakit Dengan VCO. Penerbit Swadaya, Jakarta

Warisno. 2003. Budi Daya Kelapa Genjah. Kanisius, Yogyakarta.

Wibowo, P. 2008. Penentuan Bilangan Peroksida Asam Miristat (C1499) Dari Unit Fraksinasi Di PT. Soci Medan [Skripsi]. FMIPA USU, Medan. 